\title{
WOMEN AS LAWMAKERS
}

\author{
DR. SHEILAH L. MARTIN*
}

These are the speaker's notes for an oral presenation given at the Women's Law Forum March 7. 1991 at the University of Alberta. Three speakers were asked to address the role of women as lawmakers. Martin spoke on the concept that women have not had the opportunity to contribute to legal principles or to the organization of the profession they are now entering. While it is recognized that women have made great strides in changing the legal barriers that have historically exchuded women from the law. it is argued that indirect and more insidious forms of discrimination have simply taken their place. The challenge for women as lawmakers lies in confromting these suble yet powerful forms of hias.
Loici les notes d' an exposé oral dommi ail Women's Law Forum'. le 7 mars 199l, à limiversité de l'Alberta. Trois conférencières ont parlé du rôle des femmes en tant que législatrices. Martin a souligné que les femmes n'avaient pas alu roccasion de (omtribuer à l'álaboration des principes juridiques ont a lomgamisation de la professiom à haquelle elles accide'nt anjourd'hui. S̈il est e'mendu que les femmes ont beancontp progresssi at ont rébssi à surmomter les obstacles qui les araient eiloigneses historiquement de la pratique du dioit. cerraines formes de discrimination indircetes et plus insidienses anraiemt tout simplement remplacé les barrières du passé. Les fintures légisharices derrom faire face à ce type de prejugés subrils mais nom moins puissamts.

The critique of a flawed status quo is the first step toward lawmaking. In this respect, I see a key role for feminist jurisprudence. The grand goal of feminism is to promote the equality of women and men. Its methodological secret and distinguishing feature is that it takes into account and trusts as truthful what women say about their lives. When women say they were sexually abused by their fathers as children, unlike Freud who constructs a megatheory of penis envy and father fantasy, feminists accept and believe that it could actually have happened. When women say they are beaten by their husbands or boyfriends, their testimony is treated as trustworthy. Women began to share what was once thought to be their own isolated and individual experiences and learned what was really going on in the lives of other women through conversation and the breaking of traditional silences. And like all knowledge, once women knew, they could never unlearn it and go back. Women's first step as lawmakers was, therefore, to define and name the problems women face as women; to talk and listen and have confidence in what women say. Subsequent steps in the lawmaking process involved giving names to previously undefined phenomena (like sexual harassment, domestic violence and child sexual abuse), asking and attempting to answer what Jill McCalla Vickers refers to as non questions,' taking action and coping with the continuing and colossal effort required for women to intrude into the legal system.

My main theme tonight will be the many ways in which women have been excluded from the lawmaking process. Before I proceed, I should disclose that if I heard what I am going to say when I was a law student, I would probably have been somewhat sceptical and a trifle depressed. I went to law school in the late 1970's at a time when there was a dramatic increase of females into what had always been the male preserve of

This spech was presented at the Women's Law Forum Symposium on Women as Lawmakers. March 7, 1991 at the University of Albertil.

J. McCalla Vickers, "Memories of an Ontological Exile: The Methodological Rebellions of Feminist Research" in A. Miles and G. Finn, eds., Feminism in Canada-From Pressime to Politics (Montreal: Black Rose, 1982) at 37. 
law. I was inclined to interpret my mere presence in law school as proof that the male bastion was, if not quite dismantled, then at least significantly under seige. At that time, I thought law was neutral, objective and somehow mystically above the political process which generated it. I believed that judges applied law using a near scientific method to reach the singular, logical and almost preordained right answer or conclusion. And to the extent that I would even consider that the law might operate unevenly or be used to serve competing interests, I sincerely hoped that those who had less in life had more in law. ${ }^{2}$

Today I think differently. After studying the law for fourteen years, I have begun to see the persistent pattern of women's exclusion. I originally classified things like withholding the vote from women or preventing women from owning property or entering into contracts as isolated historical abberations. But as I continued my inquiry I found that there were simply too many examples of legally supported exclusion to dismiss them as isolated. Some of the examples were so recent they could not be discounted as historical anachronisms. Obvious examples included the legally sanctioned disqualification of women from public office and the practice of law ${ }^{3}$ and the marital rape exemption under which it was legally impossible for a husband to rape his wife. ${ }^{+}$I found it difficult, if not impossible, to reconcile the reputed centrality of physical security and bodily integrity in our legal system and the fact that wives were categorically excluded from those fundamental principles in the name of the marriage contract and for the sake of a hypothetical marital harmony. In my view, the marital rape exemption is a perfect, and recent, example of a law which served male interests and substituted male desire for female autonomy by excluding women from even the most basic guarantees. This example of legislatively supported gender bias lasted until 1982, and there was a certain reluctance on the part of some lawmakers to see it go.

In relation to women as lawmakers, we can and must learn important lessons from these obvious examples of exclusion and sex discrimination. First, in each case women were grouped together and excluded solely because they were women. Second, women's exclusion was widespread; it was not aberrant or anomalous. It is important to appreciate that even one case of exclusion becomes a precedent and such a precedent shapes the way in which similar and subsequent questions are approached. In relation to women's exclusion, the case was repeated and a pattern was established. If one spans legal history, the exclusion of women has occurred so often, so recently and in so many different areas that it is impossible to dismiss legally sanctioned sex based exclusions as isolated illustrations of outmoded thinking.

The recurring patterns of exclusion and their modern relevance teach us that we must keep this history alive and use it as the starting point of our analysis of women as

2. This expression is taken from M.R. MacGuigan. "Sources of Judicial Decision Making and Judicial Activism" in S. Martin and K. Mahoney, eds., Equality and Judicial Neutrality (Toronto: Carswell. 1987) at 30.

3. See generally C.B. Backhouse. "To Open the Way for Others of My Sex" (1985) I Canadian Joumal of Women \& the Law 1.

4. See Criminal Code, R.S.C. 1970, c. C-34, s. 143: C. Boyle, "Married Women Beyond the Pale of the Law of Rape" (1981) I Windsor Yearbook of Access to Justice 192. 
lawmakers and women in law. We should not allow historical distance to erode the fact that blatant examples of exclusion did happen. We must resist the sort of revisionism which would deny that women have been systematically denied full legal personhood and deny that power, even today, is distributed on the basis of gender. We should not let the past be dismissed on the basis that it is old news and much has changed since then. This revisionism is happening today over an incident as clear and as recent as the Montreal Massacre. Even though the murderer admitted that his actions were directed solely at women, and solely because they were women, there are some who are prepared to reinterpret his crime and remove its defining characteristic by claiming that it had nothing to do with gender and that he would have done this anyway. We must jealously guard even clear examples, insist upon their true meaning and question who benefits when even the actual is denied and the obvious is obscured.

We must recognize that the past continues to shape our thoughts and affect our daily lives. Historical instances of women's exclusion teach us to be leery and weary of justifications of women's disadvantage which tie women's sexual subordination to their biological difference from men. We are all familiar with the quotes which attempt to transform a woman's biology into her destiny and to reinterpret her reproductive capacities and impose them as limits. ${ }^{5}$ It is important to recognize that men and women are equally as different from each other and there is no logical way to determine whether men or women are gender typical. ${ }^{6}$ We must question what it is about the female phenotype which prevents the simultaneous or sequential use of their brains and their uteri? The closest I have ever come to any explanation could be found in a list of myths about women's sexuality. It was once thought that when a women studied, all her blood went to her head and this "unnatural flow" impaired her reproductive abilities. This same list contended that for a women to have an orgasm is as debilitating as a day's work.?

When lessons taught by obvious examples of exclusion are understood, it is easier to appreciate that the tardy repeal of legal disabilities is not a great advance in women's rights and women should not be content with the mere removal of previously imposed barriers. These lessons counsel that a change in a discriminatory law does not automatically eradicate the biased thinking that may have generated and sustained it. Rather than a metaphor where legislative repeal wipes the slate clean and erases sexist attitudes, the reality is probably more like using a tube of toothpaste with holes in it: when you push at sexism, it tends to squish out regardless, and the end result is still a mess. Women act with the hope that the gender bias against them is reduced but recognize that it is more often transformed than terminated. This is why law reform is best approached as a process which will continue as long as sexist attitudes persist.

5. A classic formulation is found in Bradwell v. Illinois (1873) 16 Wall. 130; where the judge explains why he believes women are ill suited for the practice of law.

6. See C.A. Mackinnon, "Difference and Dominance: On Sex Discrimination" in Feminism Unmodified (Cambridge: Harvard University Press, 1987) 32, and her ground breaking work. The Se.vinal Harassment of Working Women: A Case of Discrimination (New Haven: Yale University Press, 1979): "Making Sex Equality Real" in L. Smith et al., eds., Righing the Balance: Canala's Ne's' Equality Rights (Saskatoon: C.H.R.R.. 1986) 37.

7. $\quad$ "Once Popular Myths About Female Sexuality" (Summer 1990) Woman of Power at 65 
Even recent developments illustrate how, and how often, the obvious exclusion of women is not so much stopped as replaced by its more subtle variations. For example, it would be incorrect to assume that the type of thinking which favoured men and devalued women disappeared when the marital rape exemption was repealed. The notion that a social relationship between a man and a woman, even one short of marriage, suggests the sexual availability of the woman, and on the man's terms, remains a prevalent notion in modern sexual assault judgments. ${ }^{8}$ Note how date rape is often treated as a less serious offense rather than a more dramatic and shocking violation because she knew and potentially trusted the man who violated her. Or take the idea that a women is still not equally free to drink with a man without being seen by some to sacrifice her personal inviolability. The drinking relationship means she was asking for "it" or should have expected "it." Just as the marital relationship meant she was deemed to have legally consented to "it."

Direct discrimination is often displaced by the indirect, and when the intentional is exposed and eradicated the underlying structures of systemic discrimination may nevertheless remain. When blatant forms of discrimination become unacceptable, they often go underground and women desperately want to think that because we no longer hear the comments, they are no longer made. Today many people are sufficiently sensitive not to say certain things to women's faces, but women know that the sexism is there: insidious, shaping their behaviour, limiting their options and harder to deal with because the old arguments based on women's destiny being naturally and biologically based have been replaced by more sophisticated claims. Unfortunately the issue is too often framed as one of personal competence rather than group based inequality. For example, many women are led to believe that they were not retained after their period of legal articles because their work was not up to standard. There are numerous tragic stories of very able women redefining themselves and thinking they had reached the limits of their competence only because they had been the victims of discrimination.

The exclusion of women can be likened to the shutting of a door. Sometimes the door is slammed shut. When it is, the shock, violence and vehemence of the message triggers rightful indignation and tends to mobilize those affected. There are, however, other times when the door is closed quietly but firmly. A man shakes a woman's hand smiling, providing a culturally acceptable explanation as to why it is she is not yet ready or suited for entry. These are the harder cases to fight. They are often experienced as individual failures and represented, again, as isolated incidents. But understanding women's history of exclusion helps us to appreciate that they are often neither. They are just as likely to be one of the consequences of systemic discrimination against women. Whether the door is slammed or closed quietly, there is no changing the fact that women are on the outside and they are faced with the choice of silently walking away, planning an alternative way or banging on the door, breaking the quiet and literally disturbing the peace. Women, like members of other disadvantaged groups, know what an effort it takes to be a nuisance. 
I have been using the word exclusion because it implies a keeping out by force. It conveys that there is a choice of who receives what access. Exclusion suggests that some are not selected by those who have captured the power to allocate benefits and distribute burdens. For the most part, many people recognize that women are an excluded and disadvantaged group. Given the Supreme Court's purposive reading of the Charter, this recognition is important when women seek the protection of its equality guarantees. While the terms of the equality debate have encouraged people to focus on women's disadvantage, I want to draw attention to and explore two components of this accurate but incomplete formulation of women's social position. First, it should be the verb of disadvantaging to show that inequality is a process, not a fact, and that inequality is an ongoing event rather than a natural state. The verb form of disadvantaging shows that women's secondary social position is being actively created and repeatedly reinforced.

Second, our current organization does not just disadvantage women; it confers a largely unacknowledged privilege on men. The language of disadvantage may reinforce the idea that there is an appropriate distribution according to merit, and where the implication is that social goods are unequally allocated, there is a good reason for women not receiving their share. This approach embraces victim blaming and fails to appreciate that men have historically appropriated certain privileges and rights for themselves and have at the same time denied that this self selection was a political choice. Obviously, they had good legal advice.

If we acknowledge that existing social and legal arrangements actively benefit a certain group, our vantage point may change. The burden of proof seems to shift to those who seek to maintain their privileged position and further entrench their unearned entitlements. Take, for example, the case of affirmative action programs for women. Of course, many forget that they are expressly authorized under s. 15(2) of the Charter. Those who claim they are a form of reverse discrimination often approach them ahistorically and with only the disadvantage of women in mind. To these people, employment equity programs are seen to be conferring a benefit on women which is supposedly unavailable to men. However, if we view these programs through the lens of male privilege, rather than focusing on female disadvantage, our recorded history looks like an affirmative action program for white able bodied males where men have unjustly expropriated a disproportionate share of society's goods and asymmetrically allocated society's bads to women and others.

This is a very difficult argument for many to accept. Peggy McIntosh, an Associate Director of the Wellesley College Centre for Research on Women commented that while men are often willing to grant that women are disadvantaged, they are less likely to admit that they are overprivileged. She describes privilege as an: 
whites do not see whiteness as a racial identity, so too men do not see their maleness as a gender identity.

As women started to enter latw, and other aspects of the so called public sphere. they began to scrutinize existing structures and argue that they had not been consulted when men established "just the way things are." When complete exclusion stops and the outsiders are let in, they begin to understand how the system works and they can formulate the type of questions the existing structure is bound, on its own terms, to take seriously. From the inside, the choice of legal principles does not appear as natural and politically disinterested as it is represented to be. Women began to question why they were so obviously excluded from what were claimed to be fundamental legal protections bestowed on everyone. From the inside, women adopted a notion of law from the bottom up, and women became changemakers because only then would lawmaking be responsive to their needs. Women also sought to become lawmakers in the wider sense of the word and in relation to social laws, women would help lay down the law between the parties; participate in the construction of the world around them; and formulate the ways in which men and women interact. The personal is as political today as it was in the consciousness raising sixties. Gloria Steinem's call for outrageous acts of everyday rebellion captures the need nicely."

Women know that male power is not merely legislative, judicial or constitutional. The power men have over women is pervasive, invasive, minute, exacting, and it occurs daily. It is shown most brutally in something like sexual assault, but it exists as male privilege in something as common as conversation. Women are often perceived to be dominating the conversation when they take up one third of the available time. This means that contrary to the stereotype that women control mixed sex conversations, these statistics show that women spend most of their time silent, listening and asking supportive, open ended questions. The idea of the chatty women may be yet another ideological device to keep women quiet or nervous about saying too much.

This experience is repeated in many mixed sex social situations, business mectings or law school classes. How often have you seen obviously intelligent women not contributing all that they are able to the discussion, or the points advanced by women are dismissed or marginalized unless they are repeated and translated by a man? Or what about what has sometimes been called the "glass-ceiling" - the invisible yet magic number of when there is seen to be enough women managers, law partners, law professors, Supreme Court judges, etc.?

This phenomenon requires action on the part of all women because increasing the number of women alone will not have the desired impact. Further, if we were prepared to trust women's increased participation in various public spheres, sociologists predict that even with law school participation rates for women hovering around forty percent, it will Freedom.

i1. G. Steinem. Outrageous Acts and Everyday Rebellions (New York: Holt. Rinehan \& Winston. 1983). 
still take at least another generation for women to have a significant impact on the legal profession because they are entering what has been historically an exclusively male population. Women must learn to speak up, even when they are unsure, and to be confident in their equal right to occupy space and take up time.

It should come as no surprise that because the professional norms against which the performance of all lawyers are measured were defined largely by men, they are largely male defined. For example, a common concept of professional commitment is premised on the old traditional family structure where the man could dedicate himself to the job because there was a woman, usually a wife, who took care of all the husband's and family's needs. It is easier to go home from work late at night and be fresh the next day if the underwear fairy has everything magically folded away neat and clean in the drawer. In this world, the personal is to intervene into the professional only by the presence of a five by seven family photo placed inconspicuously on the desk. Interruptions created by child care responsibilities are not factored in at all, let alone at a pressing or fundamental level. Of course, in today's world, it is as impossible for all people to fit this mold as it is for women and men to compete with those who still benefit from it. And even to the extent that a firm attempts to accommodate a parenting role, the people, mostly women, who call for and take advantage of the 'innovations' are often perceived to be less committed lawyers. If the structures continue to operate to exclude women, can we honestly say that women are choosing to leave - are they being forced out or are they opting out? What really is the problem when a person, more often a woman, decides that she will not submit to a requirement of 2300 billable hours a year? The seven years to become a partner in a law firm not only parallels, but usually occurs at the same time as women's child bearing and primary child rearing years. The role of the "working mother" was not considered when employment norms were set. What used to be a contradiction in terms has now become what many women experience as the superwoman syndrome and what psychologists are identifying as role strain. I think it helps to understand that the men who organized the legal profession never intended that women would be lawyers also. Many firms do not have materinity leave policies because a pregnant lawyer was not initially within their contemplation.

At this juncture I would like to digress and tell two stories knowing full well that many probably know of or have personally experienced similar episodes of women's current exclusion. The first deals with female lawyers whose male colleagues arranged a client development lunch at a local strip joint despite their range of choices. To market their professional services, these women lawyers were taken to a place where other women danced naked on their table. The women lawyers felt understandably uncomfortable: who did these women relate to and how were the men relating to them? The women stayed because they did not want to seem rude or give offense. The next day, they did not explain their feelings because they did not want to be criticized for their less than enthusiastic response. Had they complained, they expected the familiar lines: they weren't being sports, didn't they understand that the men didn't mean anything by it, it wasn't political, the men thought it would be fun, the client had a good time and weren't they team players. There was the fear that the male colleagues who set the thing up in the first place would not respond to their legitimate comments about the inappropriateness of the chosen location. In many such cases, women are not supposed to have an opinion 
on how they are treated. It reminds me of pornography - where it is not enough that the women in the pictures are forced into manipulated and contorted postures, but the pornographers go further and deny the woman's dissent by requiring her to smile, to feign pleasure, to pretend and to give the impression that she likes what is being done to her. In discussions with many people over this and similar incidents, some are of the view that nothing can be done and women should not speak up - we should just let things be. In my view, there are great dangers in letting the boys remain boys and there are advantages in a group of women simply insisting that men become aware.

The second story concerns my attendance at a lawyer's lunch when I was the only woman sitting at a table of eight men. (I now carry a pink "Token Woman" button in my purse for all such times, but I didn't have it then.) When the conversation turned to joke telling, almost without exception the subject matter chosen concerned sexual assault trials. Many of the men at the table relied on the book Court Jesters" as a source of material and as a legitimating front. This book purports to capture legal humour and convey the collective folklore of lawyers but its content excludes women and is often blatantly sexist. As I sat there, I could not determine whether these jokes were somehow being told for my benefit or whether they were being told for my benefit to show me I was invisible. In economic terms, these sexist jokes operated as market segregation where the in group not only separated itself from the outsiders (me and the women victims) but their humour sought to literally put themselves on top.

I was shocked by the gross insensitivity of it. I was the only woman there and they were joking about how men violate women. It was apparent that these men did not understand sexual assault like many women do. If they lived with the fear and the reality of sexual violence, they could not have sat there in that way and told those jokes. I realized that on issues like sexual assault there may be no common sense approach because the life experiences of men and women are not only completely different, they are completely at odds. If one has been sexually assaulted, has worked with women who have been, or is empathetic, it is extremely difficult to find any genuine humour in this sort of situation. It was obvious from their demeanours that they saw themselves as the lawyers or judges in the stories they told. It may even have crossed some of their minds that they could have been in the shoes of the accused but it appeared impossible for them to cast themselves in the role of the victim. It is also interesting to note that my professional training as a lawyer did not overcome my experience as a woman.

To say the least, I was depressed after this lunch, and I was also mad at myself for not speaking out. Although I did not laugh at their jokes, I nevertheless did not express how much like the sexual assault victim their jokes made me feel. I considered telling a joke, but didn't want to be complicitious. I knew that no amount of poking fun at the accused would erase the woman victim's sense of violation. My participation would have somehow condoned their behaviour and may have made it more difficult for women to speak up in the future because they would be met with the reply: 'Sheliah Martin told me that joke.' So I fell into the classic female strategy of silence as protest and endured the 
fallout of a severe case of the guilts for what I subsequently defined as cowardice. This is one way in which women learn to overcome silence.

These are two stories of recent exclusion in a social and not a legal setting. But such stories are an extremely important part of understanding what it means to live life in a female form. In addition to women entering into lawmaking, women must attempt to be the impetus to create the social laws between the parties. Look what happened to sexual harassment. It used to be just the way things were at work. But women discussed their work place experiences, told their stories, uncovered the discrimination and now there are laws against it. Women must tell their stories to release them, to share, to learn, to commune, to communicate and to validate our lived reality. The studies of women in the legal profession being undertaken in Alberta and other provinces should take into account that even the most reliable statistical methods may fail to provide the context, give the complete picture and tell it like it really is. (In this regard I have always found it amusing that some lawyers express a deep distrust of the relevance and probative value of the anecdotal or experiential - unless the story takes the form of a case and then of course it becomes a binding precedent.)

The participation of women in the legal profession raises many issues. We all know that the legal profession has changed women. It has taught us how to think like lawyers. As a woman, when presented with a legal problem I know what I have been taught to think, what I say I think and what I really think. After law school, women are at least trilingual. In addition, the increased number of women entering the legal profession will also change the legal profession. The influx of the previously excluded cannot be ignored - especially when they are part of a group which has been discriminated against on the basis of their sex and which often has family responsibilities. Recognizing that women have had a separate history within the legal profession helps explain why there is less than perfect integration or equality today. When confronting the problems women face in the legal profession, understanding women's history of exclusion makes it easier to place modern problems in their proper context. It does not justify the absence of action or help effect the changes required to fully accommodate women.

When we appreciate that women did not have the opportunity to contribute to the formulation of basic legal principles or the organization, structure and ethos of the profession they have now entered, there can be little doubt that women will make a difference, a radical difference and the resultant strains will not be easy, minor or temporary. Women are more than uninvited guests into the law: we have moved in, we intend to stay and we expect to own our proper share of the edifice. I end with a challenge both political and personal. It is political because it requires changes to an existing power structure. It is personal because it requires all of us to be strong and act. Anthropologist Margaret Mead claims, "Never doubt that a small group of committed people can change the world; indeed it's the only thing that ever has." 